\title{
Tax Rate and its Determinants: An Opinion from Ibn Khaldun*
}

\section{Vergi Oranı ve Belirleyicileri: Ibn Haldun'dan Bir Görüş}

\author{
Abdul Ghafar İsmail(1), Abu Bakar Jaafar(2) \\ (1) Islamic Research and Training Institute Islamic Development Bank, Saudi Arabia \\ (2) UTM Ocean Thermal Energy Centre at University of Technology Malaysia, Malaysia \\ (1)AgIsmail@isdb.org
}

\begin{abstract}
Tax is an alternative method for a country to obtain revenue for spending. But the issue arises when there are differences of opinion on the tax rate. Economists argue that to obtain higher tax revenue, it is necessary to lower the tax rate. In this paper, an analysis of tax rates is conducted by looking at the findings of Ibn Khaldun in his book Muqaddimah. This study also examines other hypotheses related to taxation. The findings show that the optimal rate of taxation can be determined.
\end{abstract}

Keywords: Ibn Khaldun, Tax Rate, Taxation Theory

Öz: Vergi, bir ülkenin harcama için gelir elde etmesini sağlayan alternatif bir yöntemdir. Ancak sorun, vergi oranı konusunda görüş ayrılıkları olduğunda ortaya çıkmaktadır. Ekonomistler, daha yüksek vergi geliri elde etmek için vergi oranını düşürmek gerektiğini savunurlar. Bu makalede, Ibn Haldun'un Mukaddime kitabındaki bulgularına bakarak vergi oranları analizi yapılmıştır. Bu çalışma aynı zamanda vergilendirmeyle ilgili diğer hipotezleri de incelemektedir. Bulgular ideal vergilendirme oranının belirlenebileceğini göstermektedir.

Anahtar Kelimeler: Ibn Haldun, Veri Oranı, Vergilendirme Teorisi

\section{Introduction}

This study is conducted by analyzing Ibn Khaldun's views on the theory of taxation. This study is motivated by a significant discovery from Ibn Khaldun's findings which states that the higher the tax rate, the less tax revenue will be collected, and vice versa. Ibn Khaldun also looks at differences in tax rate as dependent on the levels experienced by a government. According to Ibn Khaldun each government has a different stage because there is bound to be reforms. Each stages of a government has

\footnotetext{
"This article is a review of the paper presented at the "3rd International Ibn Khaldun Symposium" organized on 28-29 September 2013 in Istanbul.
} 
also different tax rates depending on the attitude of the leader. Ibn Khaldun has divided the evolution of governments into five levels. In the early stages of the state, taxes are light in their incidence, but make in a large revenue. Overtime, the leaders succeed each other, they might lose their tribal habits in favour of civilized one. Their needs and demands also grow, partly because they are used to the luxury in which they have been brought up. Hence, new taxes are imposed on their subjects and hence, raise the rate of old taxes to increase their revenue. But, the impacts on economy of this rise in taxation make themselves felt. For example, entrepreneurs are immediately discouraged by the comparison of their profits with the burden of their taxes. Consequently, production falls off, and the revenue also falls.

In the current terminology, the findings have been translated into Laffer curve (see Laffer (2004). This curve tells us that the rising tax rates, the tax revenue to be gained declines. Similarly, tax revenue will increase if the tax rate is decreased. So, there is a relationship between tax rate and tax revenue. The relationship shows that when there is a change in the tax rate, then two effects will result, namely, the arithmetic effect and economic impact.

Abdul Azim Islahi (2004) has produced an empirical study to show that the theory of Ibn Khaldun, is still relevant to current times. The discussion about taxes and expenditure for each stage of the government has also been addressed in this study. This discussion is important because the expenditure for each government has different effects on the tax rate. He has brought examples of tax practice as implemented in India. His research also finds out several important findings. First, the theory of tax base is derived from the religion of Islam. Second, taxes are derived from the religion, namely, zakah (charity tax), kharaj (land tax) and jizya (poll tax). Third, he also noted that tax cannot be imposed arbitrarily without regard for the rules of religion.

Since, the first attempt done by Boulakia (1971) in which he explores the contribution of Ibn Khaldun as fourteenth century economist, there is not much study that has been done to explore further his view. Therefore, this paper is our effort to: highlight some of the matters that have a bearing on the tax debate; suggest the hypothesis to be proposed in determining the budget of a state; and produce the empirical test of Khaldunian view on economic growth.

The remaining discussion of this paper is divided into five sections. Section two will present an insight into Ibn Khaldun's viewpoints. Section three will discuss about 
current viewpoints and lessons learned from Ibn Khaldun. Section four will discuss about Ibn Khaldun's theory of taxation in relation to the Laffer Curve. Section five produces the conclusion.

\section{An Insight into Ibn Khaldun's Viewpoints}

Ibn Khaldun's view could be linked with some of the matters that have a bearing on the tax debate. Among the matters related to the tax rate are revenue and political environment, government and spending attitude, and tax administration. According to him, a country's revenues are related to tax rates. This is because fluctuations in tax rates will affect the results. Each state has different forms of tax rates for the budget. High-spending countries need high finance. When government spends on luxury, the tax rate will begin to increase. These will then be explained in the next topic.

\section{First Viewpoint: Tax Rate}

In the debate about taxes, Ibn Khaldun said that an increased tax rate will result in revenue from taxes to be reduced and vice versa, where tax rate is decreased, revenue from tax increases. Ibn Khaldun said that at the beginning of a state, tax collected is a large amount of revenue from a small assessment. But when the government has reached its end phase, less tax revenue is obtained from a big assessment. Ibn Khaldun observed this when a government was collecting taxes in accordance with what has been specified by Islam, for example, zakah on fruit produced and livestock, sadaqah, kharaj and jizya. What has been determined by Islamic law cannot be added at will.

According to Ibn Khaldun, when the tax assessment ${ }^{1}$ and the liability to pay taxes on the people are low, it will indirectly affect people's determination and incentive to work, so that the enterprise culture will grow and increase. This is due to the imposition of lower taxes which has encouraged them to obtain satisfaction. With an

\footnotetext{
1 The meaning of tax assessment is the value set on taxable property, The Free Dictionary, 2012, http:/ / www.thefreedictionary. com/tax+assessment, [Downloaded on 16 August 2012]. Tax assessment is a tax imposed on owners and occupiers of rate able holdings located within the jurisdiction of the council, Local Authority Kulim Hi-Tech Industrial Park, 2012, "http://www.pbttphtk.gov.my/web/guest/resources/ circular/guidelines/assessment_fee" www.pbttphtk. gov.my/web/guest/resources/circular/ guidelines/assessment_fee, [Downloaded on 16 August 2012]. Property Assessment Tax is a tax imposed on all Creed / property in the area of administration of the Council based on the Annual Value and Annual Rate as provided in Section XV of the Local Government Act 1976. Hang Tuah Jaya Municipal Council, 2010, http://www.mphtj.gov.my/www/v1/services.php?ref=services6\&nav= services\&id=bm, [Downloaded on 16 August 2012].
} 
increasing enterprise culture, the total tax liability for individuals and tax assessment will increase. In contrast, when tax liability and tax assessment imposed on people are high because the government requires high revenue, it will result in burdening the cotter, farmer and every taxpayer. The impact of this burden will cause people to lose incentive in sustaining a viable enterprise culture. Baloglou (2012) said that Ibn Khaldun's view on the problem of taxation is similar to the view of Plethon Gemistos Georgios, who also assumes that heavy taxation discourages people from working. The people compare expenses and taxes on their income with income and profit, and they see the profit they get is smaller. So they give up on something considered not worthwhile.

Thus, Ibn Khaldun's view is that the increase in tax assessment will result in decreased tax revenue. Normally, the step taken to overcome problems of tax revenue is to impose an increased amount of liability on individuals. This measure is considered as compensation for the reduction which has occurred. What happens is that the assessment has already reached its limits and there is no benefit to raise it again. The financial cost of entrepreneurial activities is higher, the tax burden is also increasing and the profit forecast becomes unsuccessful. This will result in a decrease in profits, a decrease in fiscal revenue, and the government will be poor.

The above situation will produce an end result that would lead to the collapse of a civilization. This is because there is no motivation to industrial activity with its many benefits for the country. Increase in tax assessment will lead the country to bear the adverse consequences. Therefore, one way to spur the activity level of commerce and industry is by reducing as much as possible the amount of tax imposed on individuals. Ibn Khaldun said that a reduction in tax assessment of the individual will psychologically provide the incentive for him to work harder because of confidence in gains to be made.

Alatas (2009) argue that tax rate increases as a consequence of corrupt activities can also be seen as negatively affecting the economy. This situation occurs when there are corrupt officers who serve in the treasury of the country. The situation becomes more serious when there are some people who refuse to pay taxes. Government is then forced to overspend. This act will burden the economy and also the public. This is because of corruption affecting commerce. Prices will increase to cover the costs of corruption and it will lead to a decline in living standards for society, whereby the poor and lower-income class will fall into greater poverty. 


\section{Second Viewpoint: Revenue and Politics}

According to Ibn Khaldun, a government will certainly face decline, having during its rule directed its governmental power of sovereignty towards opulence. Society has become accustomed to such conditions. Their expenses have become higher than their allowances and income, which are insufficient to finance all their expenses. Those who have wealth will spend on luxury in their lives. The situation is also caused by successive generations, whereby all the income that they receive can no longer finance their extravagant spending.

Then when a ruler directs the people to contribute to war expenses for which the people the people can ill-afford, the ruler will take steps to penalize people who disobey his order, and to seize the wealth they have. Goods seized are kept for the ruler's own needs or distributed to members of his family and those who support his actions. This will cause the public to be weak and the effects will fetter the government. The increasingly luxurious lifestyle has resulted in the existing income to be insufficient to cover their needs and expenses. So the government is held responsible to overcome this imbalance. What happens at this time is that the amount of tax collected is fixed; it has neither increased nor decreased.

Once the new tax increases, an additional collection due to the increase in tax rates has its limits and cannot be raised again. And when tax collection is used to finance increased luxury and heavy expenditure, the number of the armed forces has to be reduced from the existing number before higher allowances are paid. As a result of rising affluence and higher payment of allowances, the number of the armed forces is reduced to a small number. Then the country will be weakened due to lack of military defense, giving the opportunity for foreign countries to be bold and ready to attack.

\section{Third Viewpoint: Government and Spending Behavior}

According to Ibn Khaldun, a government is founded after successfully defeating enemies and acquiring sovereignty from an earlier government. At this stage the ruler is an example to his people, through glory, tax collection, protection of property rights and military protection. Over time, the ruling party ceases to be an example to people and government acts with impunity. The government sets aside the interest of subjects and prevents them from participating in government. At this point the authorities attempt to recruit more followers who will support them, and aim to quell the spirit of togetherness in their lives. 
The government also wants to ensure that only royalty or kindred hold the reins of power. At this point, human ambitions are fulfilled, such as acquisition of property, creation of buildings that can last longer and fame. The ability of the government is then seen in terms of its efforts in tax collection, regulation of income and expenditure, supervision of reserves and planning of expenditure, construction of large buildings, large cities and towering monuments, and awarding gifts to dignitaries from foreign countries and conferring awards to respected tribal chiefs and their own people.

This level is the final stage for the ruler to hold full power over his people as a whole whereas previously the ruler had the freedom to exercise his own opinions. The strength of the authority established by the previous ruler is gratefully wielded by the successor. The nobility enjoys life and continue the tradition laid down earlier.

Every step has to be taken with caution because a false move of failing the tradition could prove to be disastrous. This is the fifth level specified by the Ibn Khaldun, where he saw that at this point, the ruling party enjoys riotous living, spending extravagantly on the aristocracy and appointing bad characters to carry out their important tasks. It is a futile effort because those selected are not qualified or competent to shoulder the tasks. They do not know what should be done and vice versa.

Ibn Khaldun tried to prove this theory based on the time cycle or the evolution of a government. Among the causes of the rise in tax rates is the attitude of extravagant spending on luxury which requires high-cost financing. Ibn Khaldun saw opulence as an obstruction to achieve sovereignty. Opulence will also lead a nation to sink in the luxury of the gains achieved. A government which is in such a strong position such that no other will think of taking over power or sharing power, the society will submit to its authority and be satisfied with what they enjoy from the wealth of the country and from the income they are permitted to enjoy.

The communities in the country will only think about the pleasures of prosperity, profitability and comfortable living as everything. Their lives are filled with grandeur. Eventually they become weak. Ibn Khaldun said that too much of opulence and enjoyment of life will cause near destruction. Affluence erodes the spirit of brotherhood which is required to form a strong government in a society. Lack of this spirit of brotherhood will cause a dramatic decline in the capacity to defend, much less to raise any claims against other countries. Finally, the country is attacked and ruled by 
other nations. This clearly shows that opulence is one of the obstacles to achieving sovereignty.

People who have to pay a sum of money would not do it unless willingly. Money from collection of tax including poll tax shows suppression and compliance which a soul with self-worth cannot accept unless they think that it is better to pay than be put to death and destruction. This situation shows how weak the kinship in the society. It will affect the ability to defend themselves from enemy attack. These communities will also be unable to make any resistance or demands. They can only obey and give in. If they can be forced to pay various taxes at all, it must not be expected that such a people would achieve sovereignty. So the government will make a strategy by raising tax rates to raise revenue in order to finance the cost of much heavier government spending.

Thus it can be said that Ibn Khaldun also associated wastage as an implication for spending on luxury. As regards expenditure, Ibn Khaldun only touched on matters that happened in his time and before. It is important to set an example for the next generation. But what about the high expenditure incurred for public needs. There are several important points emphasized by Ibn Khaldun about extravagance in spending and that taxes are not to be arbitrarily imposed on the people but must accord with shariah law.

Ibn Khaldun did not touch on how to determine whether certain expenses should be categorized as luxury spending and thus came to waste. What is important according to Ibn Khaldun, is to accord with religious commands. Thus it can be concluded that the order of priority in maqasid shariah (objectives of shariah law) may be used in determining whether an expenditure is on luxury or otherwise. However, as regards tax, the rate must be determined based on religious prescription. This indicates that the framework for expenditure is to be planned prior to determination of the tax rate. The hypothesis on budget based on Ibn Khaldun's views will be discussed later.

\section{Fourth Viewpoint: Administration of Tax}

Ibn Khaldun mentioned that in the Turkish government, the Wazir was the person in charge to collect various types of taxes such as jizya, kharaj and usyur. The Wazir is responsible for distribution of tax proceeds and finance of public expenditure and disbursement of regular salaries to the armed forces and civil servants. According to Ibn Khaldun, the department of tax revenue is an important department in a government. This department specialized in matters related to taxation. The 
department had a list of priorities related to national income and expenditure. It also kept the names of soldiers, set their wages and paid them on time.

The system of tax revenue collection was arranged by the head of tax collection and the government messengers. All information regarding taxes was recorded in a book which contained details about the amount of collection and expenses. People who handled these records consisted of competent accountants in charge of tax collection affairs. This book was known as the Diwan. The Diwan referred to the head office where the officers in charge of tax had their center of operations.

Alatas (2009) argue that Ibn Khaldun also said that the government's decision was usually unfair as only decisions based on an authentic religious caliphate, which could only endure for a short period, were based on justice. This injustice can be understood as the seizure of property and money, as well as the government decision to impose taxes which were not sanctioned by religion.

According to Md. Tahir (1995) when referring to the hypothesis of excessive expenditure or the Leviathan hypothesis in connection with the analysis of political process, the existence of the political financing factor affects efficient allocation of the fiscal decision process. Every politician who wants to contest an election will receive financial assistance to fund his campaign. This assistance requires a large amount of funds, formulation of tax policy and inefficient expenditure, in the interest of campaign financiers and voters. This leads to excessive spending in the public sector.

Empirical studies have shown that the victory of a political party to rule depends on good economic conditions during the election. This happens because government policy not only determines the size of the budget, but also affects the stability of the economy. An economic downturn will contribute to problems in a society such as unemployment and inflation. As a solution, the ruling party will take steps to inject a large expenditure, leading to excessive public spending.

\section{Current Viewpoints and Lessons Learnt From Ibn Khaldun}

The issue is what is the hypothesis to be proposed in determining the budget of a country. In determining the appropriate hypothesis, some matters in terms of economic, political, institutional, fiscal and international need to be addressed. The relationship between government spending and revenue is very important to be discussed. In the discussion of the budget hypothesis, Elyasi and Rahimi (2012) said 
that there are three schools of thought that differ on the relationship between tax and expenditure. The first school is known as tax-and-spend school as have been proposed by Friedman and Buchanan and Wagner. The second school is known as spend-and-tax school as proposed by Peacock and Wiseman. And the third school is the school which argues that government spending and taxation can change at the same time (fiscal synchronization hypothesis) as proposed by Meltzer and Richard.

\section{First Viewpoint: Tax - Spending Hypothesis}

According to Friedman (1978), tax increase will be a contributing factor to increased spending in a government. Based on this hypothesis, policy makers will ensure that revenue is collected prior to making spending decisions. This is a strategy that enables policy makers to formulate the budget based on revenue collected. This hypothesis has several weaknesses which can cause problems for the State, namely, the State is likely to be in deficit if policy makers have to make expenditures in excess of tax revenue. However, the advantage is that the burden of government debt may be reduced as the collection plan for government revenue is in advance of making spending decisions.

Richter and Dimitrios (2012) said that a study done on Greece for the period of two centuries from 1833 till 2010, shows Wagner's views to be correct. Greece is a country which is moving towards becoming an industrialized nation and the economic growth showed positive along with increased government spending. The increase in expenses was due to the increasing demand to make changes such as defense spending, public ownership participation in production, increase in population density and urban expansion. According to them, Wagner's hypothesis is equivalent to the hypothesis of Keynes, in reference to Goffman's version. This is because the Keynesian hypothesis is further proof that in Greece the public sector and public spending had a positive effect on economic growth and development of a country. Therefore, based on this hypothesis, for a country which aims for economic growth, spending in infrastructure, education, and increasing investment must be increased.

Moalusi (2004) said that Friedman has made a hypothesis that tax cuts are an alternative to the budget deficit when tax has a positive effect on government spending and tax cuts will be a cause of higher deficits which will influence the Government to reduce spending. He also stressed that Buchanan and Wagner agree that tax cuts would lead to government spending, but the relationship will be negative. They view tax cuts as causing the public to think that the cost of government programs has dropped. The effect will be that the public will demand more government programs which if implemented would result in an increase in government 
spending. High budget deficits will be seen as reduced tax revenue and increased government spending. So the solution to the budget deficit will be directed to increasing tax.

In Malaysia, research is more on the issue of Wagner's fiscal law. It can be seen based on studies conducted by Abdul Ghafar (1987) and also by Mohd Azlan and Zulkefly (1999), in which both studies support the hypothesis by Wagner that the growth of public spending is faster than economic growth. This shows that when economic growth was up one percent, public spending would be increased one percent.

The second school of thought by Peacock and Wiseman is the hypothesis that spending affects results. Zulkefly Abdul Karim (2006) said that according to this trend, increase in government spending is actually triggered by a crisis that leads to continual increase of expenses. This is because the economic crisis continues to be the cause of government spending in excess of tax revenue. This situation will result in changes to the fiscal variables, i.e., an increase of tax rates in order to resolve the crisis. This hypothesis implies that the government will decide in advance the expenses and then determine the rate of tax to be collected. The effect will cause the State to be in deficit because the government does too much spending and tax revenues cannot cover these expenses. In this situation policy makers will act to raise the tax rate.

According to Moalusi (2004), the discussion of the hypothesis by Peacock and Wiseman as well as Barro are based on their observations of disasters that occur as external disturbances involving war, political instability and natural disasters which cause an increase in government spending and tax revenue during the time of the disturbances. The solution to overcome the budget deficit is to reduce government spending. He also looked to an empirical study conducted by Jones and Joulfani in the case in the United States supports this hypothesis. They see this hypothesis for the period 1792 to 1860 . Their data support the hypothesis spend-and-tax in the short and long term causes of bilateral causality between taxes and spending. In his study also shows that Vamvoukas G. also finds that the spend and tax hypothesis also exists in the case of Greece in the short term and long-term period, in a study in which he seems to support the fiscal synchronization hypothesis.

The third school of thought takes the argument that government spending and taxes may change at the same time. The hypothesis is put forward by Meltzer and Ricardo and also Musgrave. According to Zulkefly Abdul Karim (2006), this approach adopts the view that there is a bilateral causality between the expenditure and revenue. In a 
situation like this, people in a country will determine the level of spending and taxes. It also means that the financial deficit in the current government spending will cause an increase in taxes in the future. There may be argued that increased government spending will be followed concurrently by the increase in future tax.

Al-Zeaud (2012) said that according to this hypothesis, the government will determine the spending and tax revenue at the same time based on cost-benefit analysis of government programs designed. Mioara and Florina (n.d) stressed that in a study conducted in Romania regarding the causality between public expenditure budget and national revenue, it is found that in general the results support the fiscal synchronization hypothesis. This means that government spending causes revenue and vice versa.

On review the three schools of thought are similar to the view of Ibn Khaldun. The reason is that Ibn Khaldun did not agree with tax imposition on people which was not in accordance with religious demands. This shows that Ibn Khaldun had seen that for development to be achieved to meet the needs of the people, the government should be able to increase tax rates to finance the project, if funds are insufficient to implement it. Thus, this hypothesis that the government will decide expenses in advance and then determine the rate of tax to be collected is compatible with the view of Ibn Khaldun, that spending must be prioritized to achieve maqasid shariah.

\section{Second Viewpoint: Fiscal Centralization}

According to Ibn Khaldun (2009), each state had only some colonies and territories, not more than these. This was due to the existence of a group of people who established a government, supported and upheld its strength. They must meet the requirements of a government, that is, in each province and subdued territories of demarcation. It was the only way to protect a government from enemy threats. They must also implement the national law regarding tax, revenue and so on. He also stressed that a country will face a situation whereby the character grows to become compliant and lazy.

Ibn Khaldun said that a group of people could only get power through struggle which then achieved victory, followed by the founding of a state. However, upon achieving this goal, the struggle halted. When the state was founded, the struggle was no longer kept up with tenacity. What happened was living unemployed in comfort and laziness. Life's enjoyment prevailed through living in beautiful homes and wearing fashionable dressing. 
At this time, water supply was channelled to the palace and gardens were built. What seemed impressive were exclusive clothing, food, household furnishings and household devices. Generally it can be said that life was too comfortable compared to hard work. This was the luxurious life which the society experienced so quickly. And this way of life passed on to successive generations. This lifestyle became widespread and eventually prosperity also ended.

Muji Tahir (2007) stressed that in islamic history shows that the Baitulmal (treasury) institution was the place where the caliph determined policies and made efforts to gather sources of wealth and distribute funds in priority to the rightful recipients. To make sure that state administration ran smoothly, the diwan or department was established. Various types of diwan were established, among them, diwan al-kharaj which was then expanded to include diwan al-mustaghallat which played the role of managing various sources of revenues and expenditure. Othman (2011) stated that in Malaysia also has a Budget Management System under the Prime Minister's Department which was officially launched on the 18th April 2011 to ensure that the government can effectively manage the national deficit and ensure that public spending is based on the principle of Value for Money. It means management of earnings that can provide the best return for every ringgit spent.

\section{Third Viewpoint: Optimal Tax Rate}

The Laffer curve shows that tax revenue is zero when the tax rate is $0 \%$. However, tax revenue drops to zero when tax rate reaches $100 \%$. This is because people increasingly turn to non-taxable income, tax shelters, tax evasion, and leisure time. At the tax rates between $0 \%$ and $100 \%$, the government collects maximum tax revenue. For the government to maximize tax revenue, this is the optimal tax rate. If the tax rate is still well below the optimum, the government can increase tax revenue by increasing tax rates. But, instead, when the tax rate is above the optimum level, the government can only increase tax revenue by reducing tax rates.

According to Heady (1993) to formulate an optimal tax framework is to look at the economic analysis that combines a number of criteria. It is done by using the concept of individual (or household) utility and social welfare. But, Hildebrand (n.d) one problem that arises in determining optimal tax is how to determine the tax rate. The big question is if the tax is a burden, how should the tax structure be imposed so as to lessen the burden and to maximize government revenue. 
A Lovitz curve seems similar to the Laffer curve. However, the two curves are in fact different. According to the Lovitz curve, the optimal tax revenue is not necessarily the tax rate in the middle, for example, at $50 \%$ of the Laffer curve or it may move to the right at $70 \%$.

Heady (1993) stressed, to determine the optimal tax rate, it must be seen to contain the concept of social welfare which reflects the notion of justice in the tax system. It also takes into account the higher administrative cost, the more the cost, the greater the tax revenue collected to fund government services. Lovitz curve shows that tax rates may be increased if by doing so it can further increase tax revenue. The curve shows that even though the tax rate increases, the results still achieve optimum level. If the tax rate is set at $50 \%$ only, the curve shows that it has not reached optimum level. Thus by moving to the right until $70 \%$, it can be said that the tax rate achieves an optimum level. For example, Table 1 shows the tax rates in different countries.

Table 1. Tax Rates in Selected Countries

\begin{tabular}{|c|c|c|}
\hline & Tax Rate & Application \\
\hline Belgium & $54 \%$ & $\begin{array}{l}\text { Likely to have negative growth, growing unemployment, and a } 3 \% \\
\text { budget deficit. }\end{array}$ \\
\hline Finland & $46.6 \%$ & $\begin{array}{l}\text { Finland has managed to have a stronger overall economy despite } \\
\text { its taxation. }\end{array}$ \\
\hline Germany & $45 \%$ & $\begin{array}{l}\text { High taxes and bureaucracy, thousands of Germans have upper } \\
\text { sticks for Austria and Switzerland, or immigrated to the United } \\
\text { States. }\end{array}$ \\
\hline Australia & $31.5 \%$ & $\begin{array}{l}\text { Australia has long provided incentives for the hard work, } \\
\text { entrepreneurship and risk-taking that are fundamental to sustain } \\
\text { economic growth and high standards of living. }\end{array}$ \\
\hline USA & $27 \%$ & $\begin{array}{l}\text { American citizens also have the highest income per hour worked of } \\
\text { any nation surveyed. }\end{array}$ \\
\hline Switzerland & $20 \%$ & $\begin{array}{l}\text { Switzerland's low tax rates have not stopped it from having some } \\
\text { of the leading universities in the world, a highly educated work } \\
\text { force and less than } 3 \% \text { unemployment as of } 2009 \text {. }\end{array}$ \\
\hline
\end{tabular}

Source: http://www.busmesspundit.com/12-countries-with-the-highest-lowest-tax-rates/ print/

Ibn Khaldun's Theory Of Taxation ín Relation To The Laffer Curve 
As mentioned earlier, when there is a change in the tax rate, there will be two effects on the revenue: the arithmetic effect and economic impact. The arithmetic effect of the reduced tax rate is that revenue per dollar of income tax will be lowered by the amount of reduction in tax rates. And vice-versa, when there is an increase in tax rates. The economic effect shows that there is a positive effect on work and productivity when the tax rates are decreased. According to Laffer (2004), the history of his curve is based on the theory of taxation contained in the book Muqaddimah which was written by lbn Khaldun, an Islamic philosopher and historian of the 14th Century.

The Laffer curve shows the relationship between tax rates, tax revenues and taxable income. But there are various assumptions made on the Laffer curve. Problems arise when the assumption states that the determination of the tax rate is based on the objective to maximize revenue. According to Laffer (2012), what is important is that reduction in tax rates will lead to an increase in terms of employment, income of workers and productivity that can bring prosperity to a state.

According Mitchel (2012), the Laffer curve demonstrates that the higher the tax rate, the more the tax revenue declines. An example of the application of the Laffer curve is the case of Ireland. In the chart below, it is possible to understand that there are significant changes resulting from reduction in tax rates from 1985 to 2004, as shown in Table 2. In 1985 the tax revenue in Ireland was only 1.1\%. Revenue from the tax increased the following years until in the year 2004, the tax revenue of Ireland reached 3.6\%.

Table 2. Ireland: Corporate Tax and Laffer Curve

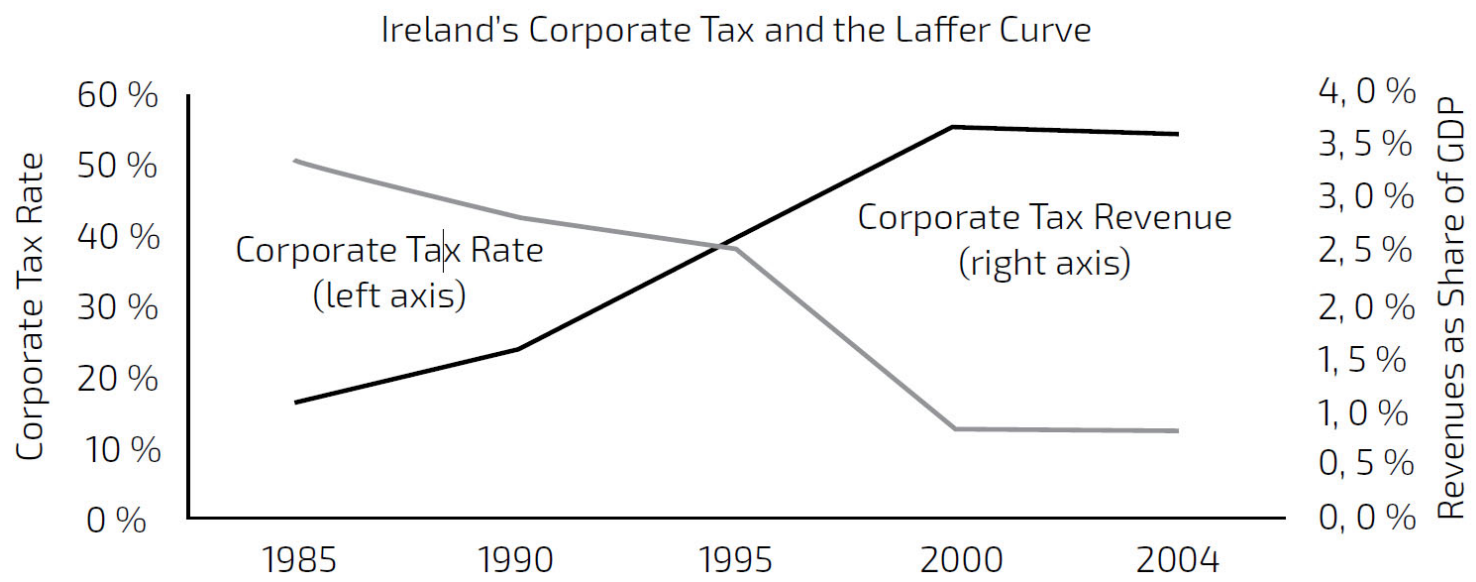

Source: Daniel J. Mitchel (2012) 
The Laffer curve shows that there is a relationship between tax rate and tax revenue. The curve indicates the need for balance in determining the tax rate. The high tax rate will affect tax revenue which as seen in the curve indicates that the higher the tax rate, the resulting revenue will be even less. This is because the tax rate will affect the economy as an incentive for employees to work.

According to Laffer, it is not the factor of the tax cut but the actual tax rate itself which affects the revenue. The response from changes in tax rates also takes into account aspects in terms of local tax system, the period of time, facilities, the existing tax rates, weaknesses in the law and the accounting procedure applied. At the prohibitive level in the curve above, it shows that very high tax rate increases tax revenue. But as tax rates rise, tax revenue increasingly declines.

To examine the relationship between tax rates and growth, a test was carried out on 10 developed countries, 10 developing countries and 10 developed countries. The time interval from 2006 to 2012 was chosen. Data source is from Index Mundi. Graphs 1, 2 and 3 explain the relationship between tax rates and GDP. Graph 1 and Graph 2 are for developed countries and less developed countries, respectively. The graphs show that the line decreased aggressively when the tax rate increases. But graph 3 show straight line extremely decreased than Graph 1. Based on the straight line for graph 1 and 3, it is understood that when the tax rate increases, the GDP also decrease. And Graph 2 is different from Graphs 1 and 3. In the sense that Graph 2 is for developing countries. It shows the straight line increase when tax rate increase. It's mean that GDP for developing countries increase when tax rate increase. However for developed and less developed countries, it shows that GDP decrease when tax rate increase.

If we refine further by looking at the points on the graph, the points are at the optimal level before they decrease. In Graph 1, the point beginning starts at the rate of $26 \%$ to $55 \%$. It also shows that many points are scattered at the rate of $45 \%$ to $55 \%$. However, Graph explains that the change in tax rates has a clear impact on growth. This can be said that the increase in tax rates contribute to the growth in the developed countries.

Graph 2 shows the starting points at 3.5\% to 137.5\%. Although this graph shows an increase in growth after an increase in tax rates, but the points in this graph are mostly at $34 \%$ up to $80 \%$. After the rate at the level $80 \%$ looks the points on the graph started decrease. It can also be said that the increase in the tax rate in developing countries also reduces growth if the tax rate increases beyond the optimal level. 
Graph 3 shows the points from $14 \%$ to $339.7 \%$. This graph clearly shows that the increase in tax rate will result in a decrease in growth of less developed countries. At the rate of $20 \%$ to $40 \%$, it seems that many points are located after the rate of $40 \%$, then the points start to decline. This shows that the optimal tax rate is less than $40 \%$ for less developed countries.

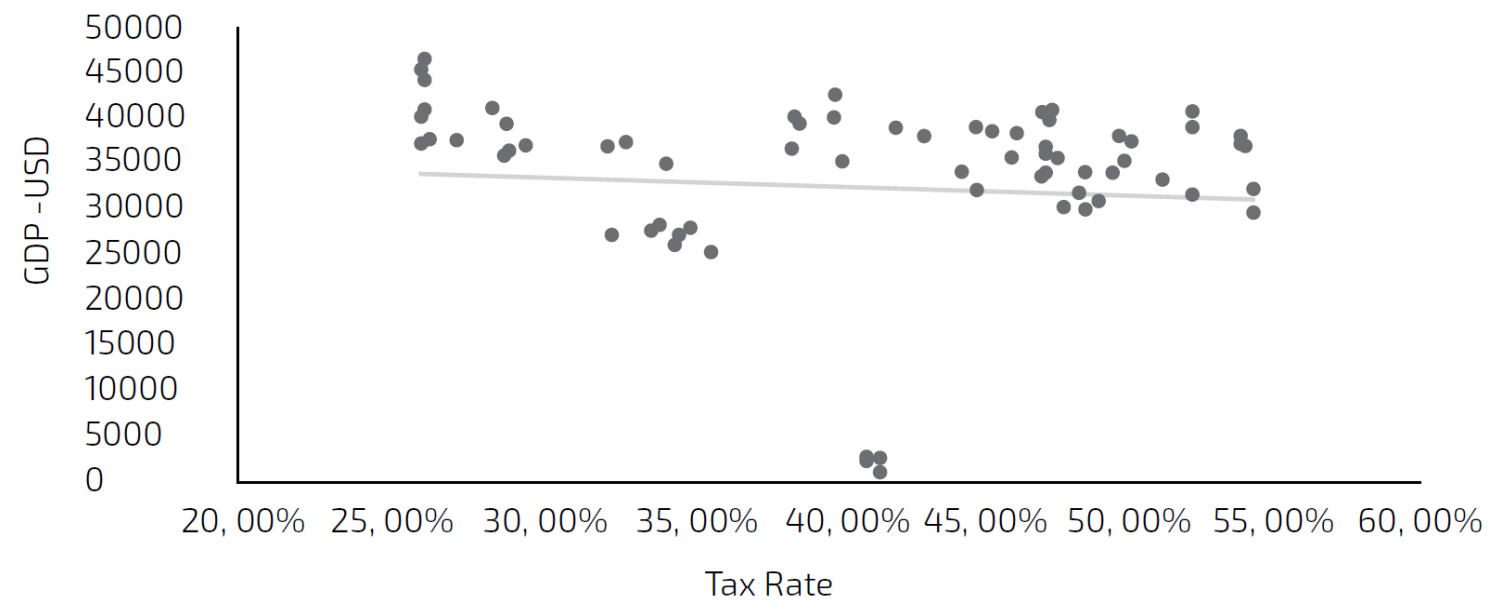

Graph 1. Tax on Growth on 10 Developed Countries

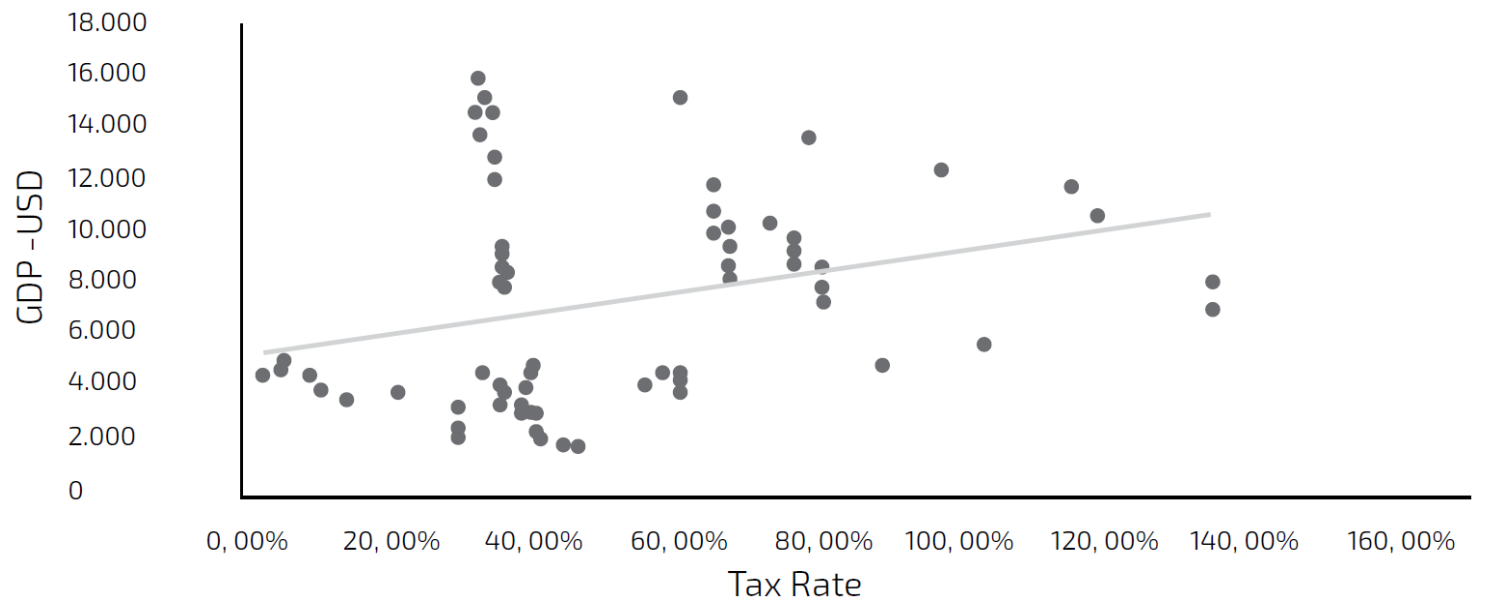

Graph 2. Tax on Growth on 10 Developing Countries 


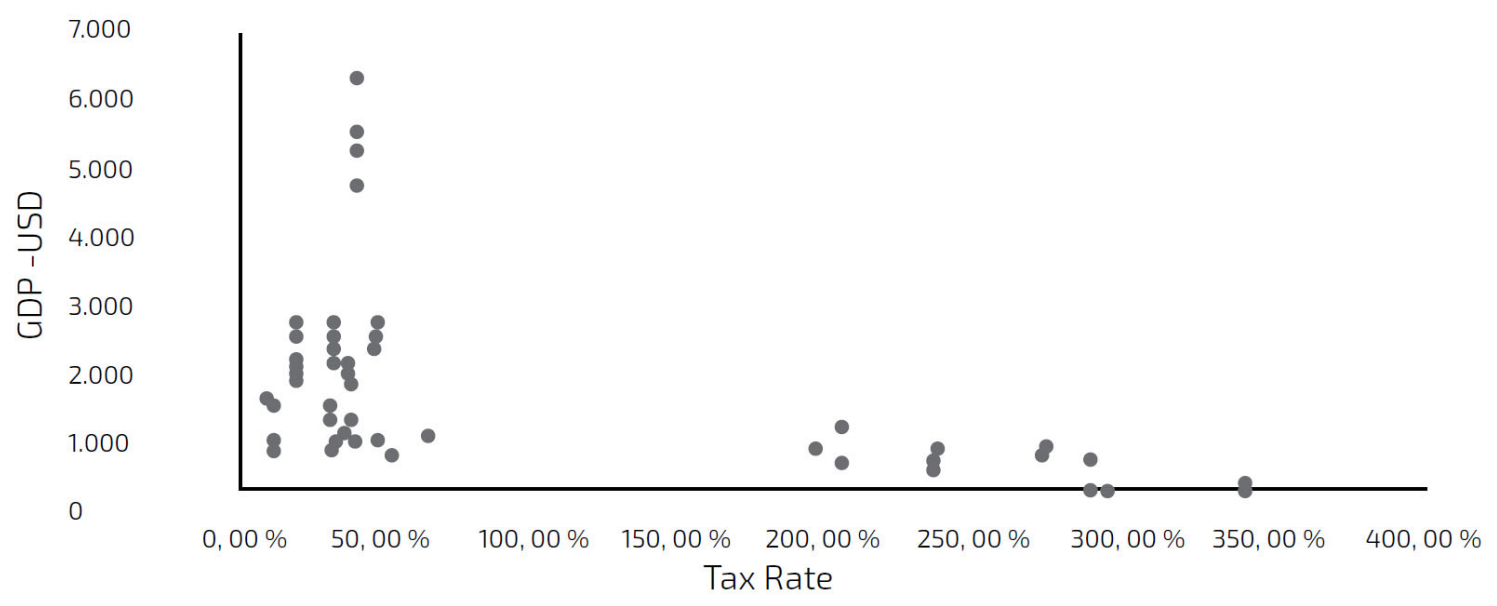

Graph 3. Tax on Growth on 10 Less Developed Countries

\section{Conclusion}

The discussion about tax rates shows that Ibn Khaldun was not in favour of increases in tax rates to obtain more tax revenue. This is because the higher tax rate will have a negative impact on work motivation of the people as they will lose incentive to work. People will think that if they work hard at all, they will still have to bear the burden of high taxes. Finally, they choose not to work earnestly. And this situation will affect tax revenue. Less income for the people will mean less tax to be collected. Similarly, when a lower tax rate is imposed on the people will cause them to feel motivated to work. The people's income will increase. In such circumstances the government will have the opportunity to earn more tax revenue from the high income. By looking at the tests performed on the 10 developed countries, 10 developing countries and 10 less developed countries, it shows that the theory founded by Ibn Khaldun still practical today. Results of the tests show that increasing tax rates would result in a decrease in the growth. Hence, the combination between Khaldunian and Laffer has spawned a new idea to see growth in a country after the change in tax rates.

\section{References}

Abd al-Rahman bin Muhammad bin Muhammad bin Khaldun. (2007). Muqaddimah Ibn Khaldun, Lubnan: Muassasah al-Ma'arif.

Abd al-Rahman bin Muhammad bin Muhammad bin Khaldun. (2009). Muqaddimah Ibn Khaldun, Kuala Lumpur: Dewan Bahasa dan Pustaka.

Abdul Azim Islahi. (2006). Ibn Khaldun's theory of taxation and its relevance today. Organizing institutions: The Islamic Research and Training Institute, a member of the Islamic Development 
Bank Group, in collaboration with Universidad Nacional de Educacion a Distance (UNED) of Spain, and Islamic Cultural Centre of Madrid, Venue: Madrid, SPAIN. 3-5 November 2006. p. 1-24.

Abdul Ghafar Ismail. (1987). Pertumbuhan Perbelanjaan Awam di Malaysia, 1960 - 1986. Kertas Kerja Kursus Pembiayaan Awam, Fakulti Ekonomi, UKM. Tidak Diterbitkan.

Arthur B. Laffer. (2004). The Laffer Curve: Past, Present and Future, Laffer Associates: Supply-Side Investment Research.

Campeanu Emilia Mioara \& Catarama Delia Florina. (n.d). Causality between Government Revenues and Expenditures in Romania. Finance Chair, Academy Of Economic Studies, Piańa Romană, No. 6, Room 1104, Bucharest, Romania, Zip Code 010374, pp. 174-178.

http://steconomice.uoradea.ro/anale/volume/2007/v2-finances-accounting-and-banks/37.pdf [Downloaded on 31 Ogos 2013]

Christos P. Baloglou. (2012). The Tradition of Economic Thought in the Mediterranean World from the Ancient Classical Times Through the Hellenistic Times Until the Byzantine Times and Arab-Islamic World, Chapter 2, In The European Heritage in Economics and the Social Sciences.

Daniel J. Mitchel. (2012). The Laffer curve shows that tax increases are very bad idea - even if they generate more tax revenue. http://www.forbes.com/sites/danielmitchell/ 2012/04/15/thelaffer-curve-shows-that-tax-increases-are-a-very-bad-idea-even-if-they-generate-more-taxrevenue/2/, [16 August 2012]

Daniel K. Moalusi. (2004). Causal link between government spending and revenue: a case study of botswana, Department of Economics, Fordham University. pp.1-20.

Christian Richter \& Paparas Dimitrios, (2012). The Validity of Wagner's law in Greece during the last 2 centuries, International Network for Economic Research. Working Paper 2012.2 pp.1-19. http://www.academia.edu/1836930/The_Validity_of_Wagners_Law_in_Greece_During_ the_Last_2_Centuries [Downloaded on 31 Ogos 2013]

Hailani Muji Tahir. (2007). Institusi Baitulmal dalam Pembangunan Negara. Bangi: Penerbit Universiti Kebangsaan Malaysia.

Hailani Muji Tahir, Abdul Ghafar Ismail \& Anwar Fakhri. (2009). Maqasid Syariah Pengurusan Ekonomi, Kewangan Dan Pembangunan Negara. International Seminar on Muamalat, Islamic Economics and Finance. 2009. 20 \& 21 Oktober.

Hang Tuah Jaya Municipal Council. (2010). http://www.mphtj.gov.my/www/v1/ services.php?ref $=$ services $6 \&$ nav $=$ services $\& i d=b m . ~[16$ August 2012].

Hussein Ali Al-Zeaud. Government Revenues and Expenditures: Causality Tests for Jordan, Interdisciplinary Journal of Contemporary Research in Business Copy Right $\odot 2012$ Institute of Interdisciplinary Business Research, November 2012, Vol 4, No 7. pp. $193-204$

Jean David C. Boulakia (1971) Ibn Khaldun: A Fourteenth-Century Economist. The Journal of Political Economy 79 (5): 1105-1118.

Local Authority Kulim Hi-Tech Industrial Park, (2012), www.pbttphtk.gov.my/web/guest/resources/circular/guidelines/assessment_fee, [16 August 2012]

Md. Zyadi Md. Tahir. (1995). Pengenalan Perbelanjaan Awam, Kuala Lumpur: Dewan Bahasa dan Pustaka. 
Milton Friedman. (1978). The Limitations of Tax Limitations. Policy Review. pp. 7 - 14. The Board of Overseers of the Leland Stanford Junior University

Mohd Azlan Saidi \& Zulkefly Abdul Karim. (1999). Pertumbuhan Ekonomi dan Perbelanjaan Awam dan Swasta: Analisis Teori dan Realiti di Malaysia. Dalam Pascasidang Seminar Fakulti Ekonomi, Pengeluaran Awam dan Swasta: Justifikasi dan Realiti di Malaysia.

Nur Chamid. (2010). Jejak Langkah Sejarah Pemikiran Ekonomi Islam, Yogyakarta: Penerbit Pustaka Pelajar,

Paparas Dimitrios \& Christian Richter. (n.d). The Validity of Wagner's Law in Greece during the last 2 centuries. https://editorialexpress.com/cgibin/conference/download.cgi?db_name =res_phd_2012\&paper_id=79. pp.1-20.

Selim Cafer Karatas. (n.d). Economic Theory of Ibn Khaldun and Rise and Fall of Nations. http://www.uned.es/congreso-ibn-khaldun/pdf/1 1\%20Selim\%20Karatas.pdf. [16 August 2012]

Suleiman Abbadi. (2004). Ibn Khaldun Contribution To The Science Economics, Journal of Al Azhar University-Gaza, Vol. 7, No. 1 P 41-48.

Surtahman Kastin Hassan \& Sanep Ahmad. (2010). Ekonomi Islam: Dasar dan Amalan. Kuala Lumpur: Dewan Bahasa dan Pustaka:

Syahrul Riza. (2008). Konsep Pendidikan Islam Menurut Pemikiran Ibn Khaldun : Suatu Kajian Terhadap Elemen-Elemen Kemasyarakatan Islam, Master Thesis, Science University of Malaysia.

Syed Hussein Alatas. (2009). Rasuah: Sifat, Sebab dan Fungsi. Kuala Lumpur: Dewan Bahasa dan Pustaka

Syed Omar Bin Syed Agil. (2010). An Inquiry Into The Causes And Costs Of Economic Growth: What Policy Makers Of Today Can Learn From The Muqaddimah Of Ibn Khaldun. Universiti Tun Abdul Razak.

The Free Dictionary. (2012). http://www.thefreedictionary.com/tax+assessment, [16 August 2012]. The Laffer Center. (2012). The Laffer Curve. http://www.laffercenter.com/arthur-laffer/the-laffercurve/, [16 August 2012].

Yousef Elyasi \& Mohammad Rahimi. (n.d). The Causality between Government Revenue and Government Expenditure in Iran, International Journal of Economic Sciences and Applied Research 5 (1): p.129-145.

Vincent A. Hildebrand, Optimal Taxation. (n.d). Glendon College, York University and SEDAP, McMaster University, Lecture 7. pp.1-22.

Zainol Bin Othman. (18 April 2011 ). Seksyen Kewangan, Bahagian Kewangan dan Pembangunan, Jabatan Perdana Menteri. http://www.pajpm.gov.my/userfiles/file/Ucapan\%20Yang\%20Berbahagia\%20Dato'\%20TKSUK\%20\%20Perhimpunan\%20April\%202011.pdf, [16 August 2012]

Zombie. (2012). The Lovitz Curve. http://pjmedia.com/zombie/2012/05/11/the-lovitz-curve/, [16 August 2012]

Zulkefly Abdul Karim. (2006). Hubungan Antara Hasil Dengan Perbelanjaan Kerajaan Negeri di Malaysia. Jurnal Ekonomi Malaysia 40. pp 59 - 93. 
http://www.businesspundit.com/12-countries-with-the-highest-lowest-tax-rates/print/ [29

August 2012]

http://www.conservapedia.com/Laffer_curve, [16 August 2012]

http://www.forbes.com/sites/danielmitchell/2012/04/15/the-laffer-curve-shows-that-tax-

increases-are-a-very-bad-idea-even-if-they-generate-more-tax-revenue/2/, [16 August 2012] 